\title{
NOTAS SOBRE A RELAÇÃO ENTRE DIALÉTICA E HISTÓRIA NA RECEPÇÃO DE HEGEL POR MARX
}

Márcio Egídio Schäfer ${ }^{1}$

\begin{abstract}
Resumo:
Uma parte considerável do pensamento de Marx foi moldada no contexto de sua confrontação crítica com a filosofia de Hegel. O presente trabalho pretende reconstruir esse confronto crítico abordando dois aspectos específicos: a dialética e a história. Procurar-se-á mostrar que Marx interessa-se, em distintas fases de sua produção, por aspectos distintos da dialética hegeliana. Ao ocupar-se com aspectos específicos da dialética de Hegel, Marx igualmente desenvolve concepções distintas de história. Com isso sugere-se, igualmente, que há uma relação intrínseca entre as concepções de história de Marx e as concepções específicas de dialética por ele tematizadas nos diferentes períodos de sua produção teórica.
\end{abstract}

Palavras-chave: Hegel. Marx. Dialética. História.

\section{NOTES ON THE RELATIONSHIP BETWEEN DIALECTIC AND HISTORY IN MARX'S HEGEL RECEPTION}

\begin{abstract}
:
A large portion of Marx's thought was shaped in the context of his critical confrontation with Hegel's philosophy. The present text intends to reconstruct this critical confrontation addressing two specific aspects: dialectic and history. We will try to show that Marx is interested, in different phases of his theoretical production, in different aspects of Hegel's dialectic. In dealing with specific aspects of Hegel's dialectic, Marx was equally concerned with distinct conceptions of history. With this it is also suggested, that there is an intrinsic relationship between Marx's conceptions of history and the specific conceptions of dialectics that he studied in the different periods of his theoretical production.
\end{abstract}

Keywords: Hegel. Marx. Dialectic. History.

\section{Introdução}

Uma questão particularmente importante na interpretação da obra de Marx em geral, e de sua recepção de Hegel em particular, é a recepção da dialética e a teoria da história a ela associada. O presente texto não pretende apresentar uma análise exaustiva nem da temática da dialética, nem da teoria da história em Marx. O objetivo é bem mais modesto: o texto visa argumentar a favor da tese segundo a qual tal como não há uma única recepção da dialética de Hegel por Marx, assim também não há, para Marx, uma única forma de compreender a história. Com isso sugere-se, igualmente, que o desenvolvimento de uma concepção específica de história está atrelado a uma concepção específica de dialética.

1 Doutor em Filosofia. Leciona na UFMA. Contato: schafer.marcio@ufma.br. 
Para iniciar a reflexão, pode-se levantar a seguinte interrogação: advoga Marx a favor de uma teoria geral da história, de uma história universal? Propõe Marx, à semelhança de Hegel, uma interpretação da história mundial fundada num princípio uno, que perpassa toda a história como um fio condutor? Boa parte da interpretação tradicional de Marx responde a essa pergunta positivamente. ${ }^{2}$ Servindo-se de categorizações como materialismohistórico e materialismo-dialético - expressões que, cumpre advertir, jamais foram empregadas e definidas por Marx -, essas distintas teorias buscaram interpretar a história como inteligível a partir de sua remissão a um princípio fundamentador universal, que, usando uma terminologia de Marx, busca sugerir que o motor da história é a contradição entre o desenvolvimento das forças produtivas e as relações sociais de produção. Esse modo de se reportar a teoria de Marx desempenhou, na tradição marxista, múltiplas funções. Buscou-se, adotando tal procedimento, fundamentar certas decisões políticas, apelando para a inevitabilidade de determinados eventos no processo histórico. Assim, justificava-se a necessidade de certas decisões políticas afirmando que elas decorrem de uma necessidade histórica que transcende o campo de influência dos agentes político-sociais num determinado contexto histórico. O agir político-social deveria tão somente criar as condições que facilitariam - ou pelo menos não interditariam - a ocorrência de determinados fenômenos, os quais se realizariam também de outra maneira. Se essa era uma postura teórica dominante na tradição marxista, a pergunta que se impõe ao intérprete é: pode-se derivá-la consistentemente do conjunto da obra escrita de Marx?

Uma resposta razoável a essa pergunta requer uma observação prévia. Quando se trata de Marx - como em geral nos grandes pensadores da tradição filosófica -, é impossível conceber sua obra no sentido de um bloco homogêneo de teses e argumentos, facilmente ordenáveis. Desconhecer esse fato é ignorar que Marx foi uma mente irrequieta, incansável na busca dos melhores argumentos para oferecer uma interpretação e crítica fundamentada da Modernidade. Em razão dessa característica, Marx paga o pesado tributo de sua obra escrita ter se tornado um infindável work in progress. A rigor, somente uma ínfima parte daquilo que escreveu Marx entregou à publicação. A maior parte de seu trabalho intelectual foi legado em forma de Manuscritos, como notas de uma pesquisa em andamento.

Observando mais de perto essa característica do pensamento de Marx, pode-se afirmar que ela é uma consequência do incessante processo de aprendizagem que marcou seu percurso intelectual. O seu encontro e confrontação crítica com distintas correntes teóricas e

2 Para uma exposição das inúmeras interpretações dentro do campo do marxismo que vão nessa direção, compare-se HOFF, 2016, p. 31 ss..

\begin{tabular}{|l|l|l|l|l|}
\hline Qenista Oialectus & Ano 9 & n. 18 & Outubro 2020 & p. 66-85 \\
\hline
\end{tabular}


políticas da Modernidade faz com que sua obra possa ser dividida em grandes fases, nas quais teses são afirmadas, outras são abandonadas. Num outro período, teses afirmadas anteriormente são negadas e novas teses são assumidas, ou teses de um período anterior são articuladas num novo contexto de fundamentação. Isso significa que ao tratar de Marx, uma das primeiras tarefas do intérprete é situar o contexto teórico em que Marx está apresentando as referidas teses ou os referidos argumentos. Assim, não é adequado tomar uma tese formulada por Marx num determinado contexto, isolá-la, e afirmá-la como sendo a tese representativa da concepção que Marx tem sobre um determinado tema.

Essas ressalvas são particularmente importantes quando tratamos da concepção de dialética e sua vinculação à teoria da história. No que concerne à recepção da dialética e sua relação com a teoria da história, duas fases são particularmente paradigmáticas no desenvolvimento intelectual de Marx. A fase em que Marx elabora os assim chamados Manuscritos Econômico-Filosóficos até a Ideologia Alema $\tilde{a}^{3}$ e o período no qual ele trabalha na sua Crítica da Economia Política, após sua chegada em Londres. ${ }^{4}$ Em ambas Marx acentua a importância de Hegel para o desenvolvimento de suas reflexões metódicas. Contudo, igualmente as nuances das apropriações da filosofia hegeliana por Marx aparecem com clareza cristalina, quando se lança um olhar mais detido sobre a temática da dialética e da história.

Minha tese central aqui é que tal como a "nova leitura de Marx" estabeleceu em relação à teoria do valor de Marx, a saber, que é necessário distinguir de modo claro e evidente entre Marx e o Marxismo, ${ }^{5}$ assim também é necessário fazê-lo em relação à teoria da história de Marx, pelo menos se considerarmos o conjunto da obra de Marx. Isso significa também assimilar as transformações e correções pelas quais a reflexão marxiana sobre a história passou. Dessa maneira, é possível imunizar Marx de certas críticas à sua "teoria da história". Isso é teoricamente importante, pois uma excessiva esquematização do pensamento de Marx em jargões e sua "refutação" ensejou não raro um abandono de outros domínios da teoria de Marx simplesmente pelo fato de que seu "prognóstico" relativo ao desenvolvimento histórico não ter se confirmado. ${ }^{6}$

Particularmente relevante isso é para a teoria da história do jovem Marx, pois: "Parece, como se Marx em 1847 ainda lesse a 'Lógica' sob a pressuposição de sua interpretação da 'Fenomenologia' de 1844, a qual, a partir dessa obra, quer desvelar o racional da filosofia hegeliana 'em geral' no horizonte de uma igualmente teoria da história teleológica" (Arndt, 2011, p. 224-225).

4 Essa divisão é bastante geral e certamente não dá conta de todos os desenvolvimentos da obra de Marx. Mas, para os propósitos aqui perseguidos, ela se revela suficiente.

5 Ver, para essa temática, por exemplo, Heinrich, 2004.

6 Conforme Lindner, 2013, p. 186. Ver também Heinrich, 2004, p. 127.

\begin{tabular}{|l|l|l|l|l|}
\hline Ronita Dialectus & Ano 9 & n. 18 & Outubro 2020 & p. 66-85 \\
\hline
\end{tabular}


Ilustrativa a esse respeito é a crítica de Castoriadis a Marx. Duas passagens apresentam o núcleo de sua crítica e as consequências que dela decorrem.

Ora, entretanto a experiência dos últimos 20 anos [o livro de Castoriadis, em sua versão original, foi publicado em 1975 - M.S.] sugere o pensamento de que as crises periódicas de sobreprodução não apresentam, no capitalismo moderno, nada de inevitável (a não ser, pois, na forma extremamente enfraquecida de 'recessões' menores e passageiras). E a experiência dos últimos cem anos mostra, nos países capitalistas mais desenvolvidos, nem uma pauperização (absoluta ou relativa) do proletariado nem um aumento, a longo prazo, do desemprego, nem uma queda da taxa de lucro e muito menos uma desaceleração do desenvolvimento da força produtiva, cujo ritmo, ao contrário, se acelerou em tal medida, que antigamente era inimaginável (p. 29-30). ${ }^{7}$

E, noutra passagem, assevera:

\begin{abstract}
Hoje nós sabemos que não é assim que sucede. Muito mais as forças produtivas desde uns 25 anos passaram por um desenvolvimento que deixou para trás tudo aquilo até agora imaginável. É certo que esse desenvolvimento não pôde ocorrer sem uma mudança da organização do capitalismo e teve por consequência outras mudanças; mas a substância do modo de produção capitalista não foi posta em questão. O que a Marx e aos Marxistas apareceu como 'contradição', que deveria implodir o sistema, foi 'resolvido' no interior do sistema (p. 34).
\end{abstract}

Castoriadis parece adotar aqui a tese de que em Marx há uma teoria da história universal - e que ela permitiu fazer certos prognósticos históricos - para, a partir do contexto do capitalismo regulado na Europa pós-guerra, rejeitá-la. Particularmente elucidativa é a afirmação de que a "contradição" que deveria implodir o sistema teria sido resolvida dentro do sistema. Castoriadis parece sugerir que a resolução da contradição protagonizada pelo capitalismo do pós-guerra é idêntica à melhora das condições de vida dos trabalhadores, ausência de crises e recessões econômicas. Isso significa que a pauperização é a materialização da contradição do capitalismo. ${ }^{8}$ Uma vez que essa pauperização não se concretizou, a contradição em Marx, como Castoriadis a interpreta, a saber, como tábua de impulsão da transição para o comunismo, é desqualificada.

O texto pretende, na sequência, examinar (i) se a contradição do capitalismo em Marx pode ser identificada com uma tábua de impulsão para o comunismo e se (ii) Marx concebe um conceito de contradição em que o próprio modo de produção capitalista resolve a "contradição", mas que essa "resolução" não é idêntica à melhora das condições de vida dos trabalhadores, tendo, portanto, outra função sistemática.

7 As traduções para o vernáculo, salvo quando indicado o contrário, são de autoria do autor.

8 Castoriadis certamente se orienta aqui em afirmações de Marx como: "Por fim, o salário pelo trabalho [já, M.S.] reduzido a um mínimo precisa ser reduzido ainda mais, para resistir à nova concorrência. Isso, então, leva necessariamente à revolução" (MEW EB I, p. 509-510).

\begin{tabular}{|l|l|l|l|l|}
\hline Rovista Dialectus & Ano 9 & n. 18 & Outubro 2020 & p. 66-85 \\
\hline
\end{tabular}


Para além dessa questão relativa à teoria da contradição e à teoria da história, como Heinrich demonstrou, é problemático querer extrair da teoria da pauperização uma teoria da revolução. ${ }^{9}$ A questão, qual seja: se a contradição, no contexto da Crítica da Economia Política, leva a uma implosão do sistema, precisa ser tratada com muita cautela. Essa tese certamente encontra sustentação em certas admissões filosóficas do jovem Marx influenciadas pela filosofia de Hegel. Se os críticos se baseassem somente nessas premissas e toda a reflexão de Marx sobre a história estivesse contida nessas premissas, certamente a crítica teria um grau de veracidade. Contudo, como veremos adiante, o próprio Marx tratou de problematizar semelhante interpretação da história.

\section{Dialética e História nos Manuscritos de Paris e em A Ideologia Alemã}

Os anos de 1843/44 são decisivos para a formação do pensamento de Marx. A importância deste período do desenvolvimento teórico de Marx reside no fato de que nele ele inicia um processo de superação do modelo hegeliano de crítica aos desenvolvimentos sociais e políticos da sociedade burguesa. Se na sua atuação como redator da Gazeta-Renana Marx ainda estava preso no paradigma da crítica política ao capitalismo, com a Crítica da Filosofia do Direito de Hegel esse modelo é superado. O Estado não é mais apresentado como a instância ética que deve ser mobilizada contra os excessos da propriedade privada. Também a emancipação política não será mais vislumbrada como emancipação humana por excelência, como Sobre a Questão Judaica mostrará. Essas críticas deixam entrever que, para Marx, a emancipação humana não pode ser concretizada nos marcos da sociedade civil-burguesa, exigindo, assim, uma nova forma de organização e mediação das relações sociais e políticas.

Desse modo, examinar a teoria da história do jovem Marx nos Manuscritos Parisienses e na Ideologia Alema $\tilde{a}^{10}$ exige considerar as razões pelas quais, para Marx, a

9 Compare-se Heinrich, 2004, p. 127. Quanto à posição de Castoriadis, podemos mencionar aqui a tese certeira de Heinrich: „Zu Zeiten des "Wirtschaftswunders” in den 60er und frühen 70er Jahren, wurde von den Anhängern des Kapitalismus gerne darauf verwiesen, dass die „marxsche Verelendungstheorie“ durch Vollbeschäftigung und den ständig steigenden Lebensstandard der Arbeiter und Arbeiterinnen offensichtlich widerlegt sei, was dann auch zu einem grundsäztllichen Argument gegen die Marxsche Ökonomiekritik ausgedehnt wurde: Die falsche Voraussage der Entwicklung des Kapitalismus mache deutlich, dass die Marxsche Analyse völlig verkehrt sei“ (2004, p. 127).

10 A relação entre os Manuscritos de Paris e A Ideologia Alemã não é acidental. Ambas as obras buscam fundamentar a necessidade histórica do comunismo. Sánchez Vásquez, de forma lapidar, mostra, contudo, onde reside a diferença entre essas duas obras "Cierto es que no fundamenta esa necesidad con el rigor que comenzará a mostrar a partir de un trabajo inmediatamente posterior: La ideología alemana. Pero ello no lo impide reconocer que ya en los Manuscritos encontramos un intento de fundamentación del paso al

\begin{tabular}{|l|l|l|l|l|}
\hline Renita Dialectus & Ano 9 & n. 18 & Outubro 2020 & p. 66-85 \\
\hline
\end{tabular}


sociedade civil-burguesa não é, ainda, o termo final da história. O problema da história é, pois, para Marx, coetâneo ao problema de como a transição ao comunismo pode ser fundamentada. Em outras palavras, é necessário compreender o fundamento da contradição social que, segundo o Marx dos Manuscritos de Paris, perpassa essa sociedade, para, então, explicitar a sua concepção de dialética e história.

Sem ambages, Marx afirma: "Porém, a oposição entre despossessão e propriedade é ainda uma indiferente, uma oposição ainda não compreendida em sua relação ativa, em sua relação interior, como contradição, até que ela não for compreendida como oposição do trabalho e do capital. Também sem o movimento avançado da propriedade privada, na Roma antiga, na Turquia etc., essa oposição pode se expressar na sua primeira figura. Assim ela aparece como ainda não posta pela própria propriedade privada. Mas o trabalho, a essência subjetiva da propriedade privada como exclusão da propriedade, e o capital, o trabalho objetivo como exclusão do trabalho, é a propriedade privada como sua relação desenvolvida da contradição, por isso uma relação enérgica, que dá impulso à dissolução" (MEW EB I, p. 533). Essa passagem apresenta o modo como o jovem Marx compreende a contradição fundamental que atravessa a sociedade civil-burguesa. É a propriedade privada que, por um lado, tem por sua essência subjetiva o trabalho, o qual, por outro, é excluído da propriedade. É essa exclusão do trabalho como essência subjetiva da propriedade privada da propriedade privada que é, segundo Marx, o fundamento da alienação do trabalhador e, por isso, a contradição insuperável dentro da sociedade que está fundada sobre essa forma de propriedade.

Ora, se é assim, a reconciliação do trabalhador com o produto do seu trabalho só pode ser restabelecida numa sociedade que supera a propriedade privada como seu fundamento. Dito isso, Marx passa a considerar o comunismo como a sociabilidade na qual essa autoalienação seria superada.

Cumpre observar que ideias sobre uma sociedade comunista como alternativa à sociedade burguesa não nasceram com Marx. A rigor, são tão velhas quanto à própria sociedade burguesa. Portanto, distintas ideias acerca de uma sociedade comunista como alternativa à sociedade burguesa já circulavam antes de Marx.

Dada essa pluralidade de concepções do que seja "comunismo", Marx elabora", nos Manuscritos de Paris, uma taxonomia das mesmas. A classificação proposta por Marx

comunismo y de dar a éste un sentido distinto del que tiene en algunas concepciones utópicas de aquel tiempo" (1982, p. 117).

11 Para uma exposição detalhada dessas concepções, ver Sánchez Vázquez, 1982, p. 117 ss..

\begin{tabular}{|l|l|l|l|l|}
\hline Rovista Dialectus & Ano 9 & n. 18 & Outubro 2020 & p. 66-85 \\
\hline
\end{tabular}


visa caracterizar essas distintas concepções do que seja o comunismo para, assim, delinear os contornos de sua própria concepção. Aqui se situa uma contribuição importante do jovem Marx, pois se concepções de uma sociedade comunista eram comuns à época de Marx, destoantes eram as teorias sobre como se chega até ela. Marx, pois, não é original em ter proposto o comunismo como alternativa à sociedade burguesa, mas "en haber señalado - esto sí -, por primera vez, la necesidad histórica que conduce a ella; o sea, el comunismo como fruto del desarrollo histórico y culminación del movimiento real de la propiedad privada" (Sánchez Vázquez, 1982, p. 117). Portanto, como mencionado acima, a discussão sobre a história está intrinsecamente associada à discussão sobre a transição para a sociedade comunista.

Marx vai falar de um comunismo grosseiro (MEW EB I, p. 534 ss.), que se caracteriza basicamente por negar a personalidade dos seres humanos em geral, na medida em que torna todos propriedade de todos. A tese de Marx é que o comunismo grosseiro é, na medida em que nega a personalidade dos seres humanos, mesmo que às avessas, "expressão consequente da propriedade privada, que é essa negação” (p. 534). Marx menciona o exemplo da comunidade de mulheres, a qual ele nega veementemente.

Na sequência (MEW EB I, p. 536), Marx vai falar de um comunismo "ainda de natureza política", "com a superação do Estado, mas simultaneamente ainda um ser incompleto, afetado sempre ainda com a propriedade privada, isto é, com a alienação do ser humano". 12

Após expor as duas concepções de comunismo mencionadas, Marx passa, agora, à terceira concepção, a qual é, por assim dizer, a sua. "O comunismo como superação positiva da propriedade privada enquanto autoalienação humana e, por isso, como verdadeira apropriação da essência humana pelo e para o ser humano; [...] Esse comunismo é como naturalismo completado $=$ humanismo, como humanismo completado $=$ naturalismo, ele é a verdadeira dissolução do conflito entre o ser humano com a natureza e com o ser humano, a verdadeira dissolução do conflito entre existência e essência, entre objetificação e autorrealização, entre liberdade e necessidade, entre indivíduo e gênero. Ele é o enigma resolvido da história e se sabe como essa resolução" (MEW EB I, p. 536). "A superação da

12 Marx não cita nomes de expoentes dessas duas formas de comunismo e especialmente a exposição da segunda forma de comunismo é pouco desenvolvida. Sánchez Vázquez sugere, por exemplo, que quanto ao comunismo grosseiro, Marx pensa em nomes como o de Babeuf (1982, p. 123) e, quando trata do comunismo de natureza ainda política, em nomes como Cabet (1982, p. 125). No Manifesto do Partido Comunista (MEW 4, p. 482 ss.), Engels e Marx apresentam, na terceira parte intitulada "Literatura socialista e comunista", um rol bem mais amplo de teorias socialistas e comunistas, que em parte podem iluminar e ampliar as doutrinas comunistas mencionadas por Marx nos Manuscritos.

\begin{tabular}{|l|l|l|l|l|}
\hline Ronita Dialectus & Ano 9 & n. 18 & Outubro 2020 & p. 66-85 \\
\hline
\end{tabular}


propriedade privada é, por isso, a completa emancipação de todos os sentidos e propriedades humanas" (MEW EB I, p. 540).

Mais adiante (MEW EB I, p. 447), para marcar a diferença entre a sua concepção de comunismo daquelas objeto de sua crítica, Marx vai introduzir uma distinção entre propriedade privada e propriedade individual, a propriedade que funda no trabalho do próprio trabalhador, e não na propriedade privada - o capital - como poder de disposição privada sobre o trabalho alheio. Ainda num contexto tardio, como veremos adiante, Marx vai conceber o comunismo como a superação da propriedade fundada na apropriação do trabalho alheio, ou seja, na afirmação da propriedade individual fundada no próprio trabalho.

Como, contudo, a transição para a sociedade comunista é fundamentada? Quanto a isso, Marx afirma: "Na medida em que, porém, para o ser humano socialista toda a assim chamada história universal nada mais é do que a criação do ser humano pelo trabalho humano, como o vir-a-ser da natureza para o ser humano, assim ele tem, portanto, a demonstração visível, irresistível de seu nascimento através de si mesmo, de seu processo de surgimento" (MEW EB I, p. 546). E Marx prossegue: "O comunismo é a posição como negação da negação, por isso o momento verdadeiro, necessário para o desenvolvimento próximo da emancipação e reconquista humana. O comunismo é a figura necessária e o princípio enérgico do futuro próximo, mas o comunismo como tal não é o objetivo do desenvolvimento humano - a figura da sociedade humana" (MEW EB I, p. 546).

Como fica evidente, Marx serve-se, aqui, largamente de uma concepção de dialética emprestada de Hegel - que em parte o próprio Hegel empregou no desenvolvimento de sua concepção de história. ${ }^{13}$ Central aqui é a figura da negação da negação, da qual se segue uma nova posição/afirmação.

Interessante observar que no Terceiro Manuscrito, no qual Marx se debruça sobre a dialética e a filosofia de Hegel em geral, ele esboça uma crítica a essa concepção hegeliana de dialética (MEW EB I, pp. 584-585). Marx critica a negação da negação, pois, segundo ele, Hegel reduziu o processo de suprassunção histórico a uma fórmula do pensamento, à consciência. Esse processo deve ser compreendido na concretude histórica, isto é, do ponto de vista da "matéria".

Conquanto a Ideologia Alemã tenha sido concebida a título de um ajuste de contas com a consciência filosófica anterior, ela sintetiza de maneira precisa a concepção de história

13 Sobre a posição de Marx acerca da dialética de Hegel nos Manuscritos, compare-se Quante, 2009, p. 316 ss..

\begin{tabular}{|l|l|l|l|l|}
\hline Rovista Q Palectus & Ano 9 & n. 18 & Outubro 2020 & p. 66-85 \\
\hline
\end{tabular}


já latente nos Manuscritos de Paris. ${ }^{14}$ Em outras palavras, ela expressa a tentativa de Marx em conjunto com Engels - de dar uma fundamentação materialista à dialética, uma fundamentação materialista ao desenvolvimento histórico, que Hegel teria reduzido a uma fórmula do pensamento. Marx, portanto, não pretende abandonar essa estrutura ou essa figura dialética da negação da negação formulada por Hegel, mas quer fundamentá-la de um ponto de vista materialista.

Essa concepção de história indicada por Marx nos Manuscritos de Paris experimenta, pois, uma especificação na Ideologia Alemã. A "Alienação", assim diz Marx, "para se tornar compreensível aos filósofos, somente pode ser superada sob duas pressuposições práticas” (MEW 3, p. 34). Para que essa alienação se torne uma força “insuportável”, “contra a qual se revoluciona" (idem), é necessário que "ela tenha formado a massa das pessoas completamente como "livres de propriedade" e "simultaneamente em contradição com um mundo da educação e da riqueza disponíveis" (idem). Ambas, assim Marx afirma, "pressupõem um grande aumento da força produtiva, um grande grau de seu desenvolvimento" (idem). A tese importante que se segue a essas considerações é que este “desenvolvimento das forças produtivas" é "uma pressuposição prática absolutamente necessária, porque sem ela só se universaliza a carência [...] porque, ademais, com esse desenvolvimento universal das forças produtivas é posto um intercâmbio universal dos seres humanos, por isso, por um lado, o fenômeno da massa "livre de propriedade" é formado simultaneamente em todos os povos, torna todos dependentes das revoluções dos outros e, finalmente, pôs indivíduos histórico-universais, empírico universais no lugar dos locais" (MEW 3, pp. 34-35).

E Marx conclui: “O comunismo é possível empiricamente somente como ação dos povos dominantes "de uma só vez" e simultaneamente, o que pressupõe o desenvolvimento universal das forças produtivas e o comércio mundial a ele associado" (MEW 3, p. 35). Marx, portanto, em meados dos anos 40, enquadra o comunismo dentro de um movimento histórico, cuja fundamentação filosófica é assumida, mesmo que sob um ponto de vista crítico, de Hegel. Essa concepção de história sugere, igualmente, os aspectos "materialistas" a serem considerados para fazer uma revolução histórico-universal tal como a transição para o comunismo exigiria. A impulsão dessa negação da negação, da passagem para o comunismo, exige, assim, o desenvolvimento universal das forças produtivas, podendo ter, por conseguinte, como sujeito histórico somente os “povos dominantes”. Como Lindner afirma de

14 Minha exposição sobre a teoria da história de A Ideologia Alemã se orienta pelas reflexões de Lindner, 2013, p. 188 ss..

\begin{tabular}{|l|l|l|l|l|}
\hline Q Povista Dialectus & Ano 9 & n. 18 & Outubro 2020 & p. 66-85 \\
\hline
\end{tabular}


maneira precisa, o esquema interpretativo da história construído por Marx entende a contradição entre o desenvolvimento das forças produtivas e as relações de produção como "um motor da história transhistórico-orientado para um fim" (2013, p. 187). ${ }^{15}$ Isso significa que: "Todas as colisões da história possuem [...], de acordo com a nossa compreensão, sua origem na contradição entre forças produtivas e formas de intercâmbio" (MEW 3, p. 73). ${ }^{16} \mathrm{E}$ um pouco adiante, Marx chega a sua tese central: "Essa contradição entre as forças produtivas e as formas de intercâmbio teve que explodir, sempre, numa revolução" (MEW 3, p. 74).

Que Marx, pois, conceba seu modelo de interpretação de história como uma teoria da história universal parece seguir da seguinte afirmação: “A concorrência produzida por um intercâmbio internacional ampliado com países industrialmente mais desenvolvidos é suficiente para produzir uma contradição semelhante também nos países industrialmente menos desenvolvidos" (MEW 3, p. 73). ${ }^{17}$

O que fica evidente a partir dessas breves considerações acerca das teses sobre dialética e história do Marx dos anos 44/45 é que ele de fato argumentava a favor de uma concepção universal da história e, para sustentar sua argumentação, empregava figuras da dialética de Hegel. Considerando as posições tardias, como veremos com mais vagar em instantes, Marx aqui parece estar pensando, em primeira linha, nos povos dos países industriais do ocidente como aqueles que podem impulsionar o movimento histórico em direção ao comunismo, a posição/afirmação que se segue da negação da negação, da mesma forma que as revoluções burguesas instituíram, nesses países, o capitalismo. ${ }^{18}$ Será essa, contudo, a posição derradeira de Marx?

\section{II}

\section{História e Dialética na Crítica da Economia Política}

$\mathrm{Na}$ introdução ao presente texto, sugeriu-se que a Crítica da Economia Política apresenta uma ruptura em relação às concepções precedentes acerca da história e da dialética e sua respectiva relação. Para delinear essa ruptura, ou seja, demonstrar que no âmbito da Crítica da Economia Política Marx desenvolve uma concepção de dialética, por conseguinte,

15 A tese de que nos anos 40 Marx opera com categorias transhistóricas foi detalhadamente desenvolvida por Moishe Postone em seu já clássico livro.

16 Sobre os conceitos de Verkehrsform e Produktionsverhältnisse, leia-se Lindner, p. 190 ss..

17 Esta tese é particularmente importante para as discussões sobre a história do Marx tardio.

18 Despida de sua linguagem filosófica, parece ser essa ainda a concepção de história vigente no Manifesto, especialmente na primeira parte. Ver, quanto a isso, MEW 3, p, 462 ss..

\begin{tabular}{|c|c|c|c|c|}
\hline Revista Dialectus & Ano 9 & n. 18 & Outubro 2020 & p. $66-85$ \\
\hline
\end{tabular}


também de história, distinta dos Manuscritos de Paris, é necessário certificar-se do que seria essa nova concepção de dialética na Critica da Economia Política.

Para esclarecer essas questões de fundo, cabe apresentar brevemente qual o objeto da Crítica da Economia Política. Já nos anos 40 Marx articulou uma crítica à Economia Política Clássica, influenciado pelo famoso artigo de Engels Esboço de uma Crítica da Economia Política. A crítica de Marx tinha por alvo a forma como essa ciência deduzia as categorias centrais da sociedade civil-burguesa. E essa deficiência explicativa conduzia, segundo Marx, a uma eternização indevida dessas categorias e, por conseguinte, da própria sociedade civil-burguesa nelas traduzida.

Nos seus escritos tardios, Marx objetiva mostrar como o sistema do modo de produção capitalista, isto é, as categorias que o traduzem conceitualmente, podem ser deduzidas da categoria mais elementar, que é a mercadoria. Desse modo, o desenvolvimento dialético deduz geneticamente as categorias - ou as formas sociais - que constituem a sociabilidade burguesa dessa categoria elementar. A ideia central de Marx é, pois, que da mercadoria, isto é, da contradição, da negatividade interna a essa categoria, é possível deduzir as outras categorias, valor, dinheiro, capital etc. A dialética, assim, é o método de como, de uma contradição interna de uma determinada categoria, pode-se passar a uma categoria de nível superior, que visa superar essa contraditoriedade, a deficiência inerente à categoria precedente. Assim posto, parece que a dialética de Marx - entenda-se na Crítica da Economia Política - tem uma semelhança espantosa com a dialética de Hegel, particularmente se pensarmos na lógica das determinações de reflexão, na Lógica da Essência.

Antes de tudo, para tratar da ruptura ou continuidade na concepção de dialética em Marx, é necessário levantar a questão pela própria definição de dialética. Pois como Arndt formula com muita justeza: "A dificuldade, em geral, de estabelecer tal relação [entre a dialética de Marx e Hegel] consiste também na necessidade de uma certificação prévia daquilo que seja "dialética" em Hegel” (2011, p. 217). O que é, pois, a dialética em Hegel? A meu ver, uma das respostas mais lúcidas a essa questão foi proposta por Düsing (1995) e Schäfer (2001). Ambos defendem a tese de que a dialética hegeliana não possui uma forma, sendo antes apropriado falar de formas da dialética na Lógica de Hegel. ${ }^{19}$ De acordo com essa linha de interpretação, o desenvolvimento da rede categorial da Lógica obedece ao nível de desdobramento de cada etapa da lógica. Assim, a Lógica do Ser, a Lógica da Essência e a Lógica do Conceito seriam desenvolvidas com base em formas distintas da dialética.

19 A esse propósito, o livro de Schäfer (2001) tem o elucidativo título de: Die Dialektik und ihre besonderen Formen in Hegels Logik. O autor detalha a caracterização das formas da dialética oferecida por Düsing.

\begin{tabular}{|c|c|c|c|c|}
\hline Revista Aidectus & Ano 9 & n. 18 & Outubro 2020 & p. $66-85$ \\
\hline
\end{tabular}


Conforme Düsing (1995, p. 327 ss.), a dialética possui três formas fundamentais na lógica especulativa de Hegel. Sucintamente, Düsing caracteriza cada uma dessas formas da seguinte maneira: (1) "O progresso dialético de uma categoria para a outra Hegel denomina, na Lógica do Ser, de "transitar" (Übergehen); esta é a primeira forma fundamental da dialética" (1995, p. 328). (2) “A segunda forma fundamental do método dialético, a saber, a dialética das categorias da essência, Hegel denomina de "parecer no oposto" (Scheinen in dem Entgegengesetzten) (1995, p. 330). (3) "Na Lógica do Conceito, porém, o conceito é determinado como ele é para si mesmo. Hegel caracteriza o progresso específico de determinação em determinação na Lógica do Conceito como 'desenvolvimento' (Entwicklung); ela forma a terceira forma fundamental do método dialético. Nela, o automovimento do conceito encontra sua expressão adequada" (1995, p. 331).

Essa esquematização da dialética na lógica especulativa de Hegel é bastante esclarecedora e permite iluminar os possíveis usos ou apropriações que Marx fez da dialética hegeliana. Contudo, nem todas as dificuldades podem ser tratadas nesse esquema. Particularmente se examinarmos a dialética de Hegel pelo viés crítico de Marx, qual seja: que a dialética de Hegel possui um lado místico e um lado racional. A face mística e a face racional da dialética comparecem em toda a extensão da Lógica, não podendo, por conseguinte, ser atribuídas a esta ou àquela forma particular da dialética na lógica de Hegel. Não há como detalhar pormenorizadamente esse problema aqui, mas para fins de compreensão, basta recordar que a passagem lógica do finito ao infinito, base do idealismo hegeliano, portanto objeto da crítica de Marx, é desenvolvida na lógica do ser-aí, na Lógica do Ser. ${ }^{20}$ A questão chave aqui é que a contradição do finito faz com que ele necessariamente transite ao infinito. Aqui Hegel funda o que Arndt denomina de "mecanismo de suprassunção teleológica” (1994, p. 216), que orienta também as reflexões sobre a história do jovem Marx. ${ }^{21}$ Nesse mecanismo, as contradições do finito são suprassumidas na positividade do infinito, que dispõe de uma dignidade ontológica superior. Essa é a razão pela qual o finito somente pode subsistir no infinito. Da mesma forma, na Lógica do Conceito, onde esse idealismo é desenvolvido em todas as suas consequências, tem-se um aspecto não místico, que reside justamente na clareza com a qual Hegel mostra o que é o conhecer conceituante, isto é, a redução das múltiplas determinações de um objeto à sua unidade. ${ }^{22}$

20 Conforme Iber, 1999, p. 119 ss..

21 Compare-se, quanto a isso, Arndt, 2011, p. 224-225.

22 Para uma compreensão mais aprofundada sobre a Lógica do Conceito, ver Iber, 2002.

\begin{tabular}{|l|l|l|l|l|}
\hline Ronista Dialectus & Ano 9 & n. 18 & Outubro 2020 & p. 66-85 \\
\hline
\end{tabular}


O ponto nodal para compreender a intricada relação entre dialética e história é a correta apreensão do conceito de contradição, tal como Hegel o articula no âmbito da lógica do ser-aí, e o conceito de contradição de Marx no âmbito da Crítica da Economia Política. Marx escreve que: "Der in der Waare eingehüllte innere Gegensatz von Gebrauchswerth und Werth wird also dargestellt durch einen äußeren Gegensatz, d.h. durch das Verhältniß zweier Waaren [...]" (MEGA ${ }^{2}$ II/6, p. 93; MEW 23, p. 75). Ou seja, a oposição interna à mercadoria entre valor-de-uso e valor é apresentada numa oposição externa. Ou seja, essa oposição, como Marx observará mais adiante, produz a duplicação da mercadoria em mercadoria e dinheiro. $\mathrm{O}$ dinheiro é, pois, a apresentação da oposição entre valor-se-uso e valor, interna à mercadoria, numa oposição externa. Nos Grundrisse Marx constata: "O dinheiro só pode suprassumir as dificuldades que residem no intercâmbio mercantil, na medida em que as generaliza, as torna universais" (MEW 42, p. 84). Isso significa que a contradição não é superada, mas ela persiste numa contradição externa e, com efeito, numa contraditoriedade potencializada. A contradição, desse modo, conserva-se ao produzir uma forma na qual ela pode se movimentar. A contradição, pois, não é "resolvida" no sentido de fazê-la desaparecer, muito menos ela tem a função de implodir o sistema. Antes ao contrário, a contradição é a forma como o sistema da economia burguesa se movimenta para reproduzir-se enquanto sistema, isto é, produzir uma forma de transcurso para as suas contradições. Essa "solução", isto é, o criar-se uma forma para seu transcurso, "é a forma imanente de sua solução" (Arndt, 2011, p. 238). É, portanto, a maneira como o sistema do modo de produção capitalista se reproduz, e precisamente repondo a contradição das formas elementares num nível superior ou, como Marx diz, universalizando-as. ${ }^{23}$ Aqui se manifesta o que Marx já havia afirmado nos Grundrisse, a saber, que o modo de produção capitalista enquanto sistema é um todo orgânico, que gera a partir de si mesmo os órgãos necessários à sua reprodução enquanto sistema. ${ }^{24}$ No mesmo contexto, ainda, Marx fala que o sistema da economia burguesa torna-se, assim, "historicamente em totalidade" (MEW 42, p. 203). Com isso desvela-se o específico da teoria da contradição do Marx tardio: “A contradição não marca, para Marx, o fim do objeto 'modo de produção capitalista', o ponto de ruptura entre dois sistemas, mas precisa ser compreendida de maneira imanente" (Arndt, 2011, p. 237). O conceito de contradição assim desenvolvido é, pois, infrutífero para a construção de uma teoria da história universal teleologicamente orientada, pois, para além do fato de carecer de um sujeito do processo histórico, como o espírito hegeliano, não leva à transição inevitável de um sistema econômico para outro, como

23 Paradigmáticas, quanto a isso, são as contradições relativas às crises da sobreprodução.

24 Ver MEW 42, p. 203.

\begin{tabular}{|l|l|l|l|l|}
\hline Ronista Dialeatus & Ano 9 & n. 18 & Outubro 2020 & p. 66-85 \\
\hline
\end{tabular}


muitos críticos de Marx acreditaram. Para o Marx da Crítica da Economia Política, a contradição restringe-se ao sistema histórico e finito da economia burguesa. ${ }^{25}$ Da negação da negação não se segue uma posição.

Um olhar rápido sobre as formas de dialética na lógica de Hegel deixa entrever que particularmente a terceira forma fundamental da dialética, a dialética da lógica do "desenvolvimento", parece ser propícia para a construção de uma teoria da história universal. Esse modelo parece ser propício, pois permite explicar a história a partir de um princípio uno, o espírito, a razão, ao qual os momentos históricos são reconduzidos, afirmando-os como manifestação deste princípio. ${ }^{26} \mathrm{E}$ é esse princípio uno que confere unidade à multiplicidade dos eventos históricos. Contudo, não há como ignorar que esse modelo lógico do desenvolvimento já está, de certa forma, prefigurado na Lógica da Essência, no desenvolvimento das determinações de reflexão. Já nesse contexto Hegel desenvolve o modelo lógico de uma lógica do restabelecimento, onde a identidade perde-se na diferença, para, ao fim e ao cabo de seu desdobramento lógico, no fundamento, tornar-se uma unidade da identidade e da diferença.

Contra a tese de que haveria uma ruptura com a concepção juvenil da dialética e da história fala, num primeiro momento, o fato de que ainda em $O$ Capital teses centrais da primeira concepção de dialética se fazem presentes de maneira inegável. Particularmente duas passagens sintetizam, no contexto do capítulo 24, esse pensamento da história do jovem Marx.

\begin{abstract}
A centralização dos meios de produção e a socialização do trabalho alcançam o ponto em que elas se tornam incompatíveis com seu invólucro capitalista. Ela será explodida. A hora da propriedade privada capitalista bate. Os expropriadores serão expropriados (MEW 23, p. 791).

O modo de apropriação capitalista que se desenvolve a partir do modo de produção capitalista, por isso, a propriedade privada capitalista, é a primeira negação da propriedade privada individual fundada no próprio trabalho. Mas a produção capitalista gera com a necessidade de um processo natural a sua própria negação. É a negação da negação. Essa não repõe a propriedade privada, mas bem a propriedade individual com base na conquista da era capitalista [...] (MEW 23, p. 791).
\end{abstract}

O que cabe examinar aqui é se o uso dessas teses da filosofia da história juvenil pelo Marx maduro são legítimas ou não, isto é, se são compatíveis com a concepção de dialética e, em particular, com o conceito de contradição desenvolvido em $O$ Capital. Marx

25 Como Iber observa: "Marx legt wie Platon im Sophistes Dialektik auf Endlichkeit fest [...]” (2007, p. 376). Ora, se a dialética está fixada à finitude, parece pouco plausível querer mobilizá-la para impulsionar o finito ao infinito.

26 Na Introdução à Filosofia da História formula assim sua tese: “[...], que a razão regeu o mundo e, assim, também regeu a história mundial" (TW 12, p. 40).

\begin{tabular}{|l|l|l|l|l|}
\hline Rovista Dialectus & Ano 9 & n. 18 & Outubro 2020 & p. 66-85 \\
\hline
\end{tabular}


ainda aposta na tese de que cabe aos povos dominantes entrar em cena no teatro da história para fazer a revolução comunista? Como Arndt (2011, p. 99) destaca, essa posição de Marx foi profundamente discutida pelos "reformadores e revolucionários" russos, isto é, a questão se a Rússia precisaria passar pela fase do desenvolvimento capitalista dos países industrialmente avançados, como essas teses da filosofia da história parecem sugerir. Como Arndt observou com acribia: "Parece que particularmente o discurso hegelianisante da negação natural-necessária da produção capitalista, que, como negação da negação, restabeleceria a propriedade comum, ter jogado um papel nisso" (2011, p. 99).

Para Lindner (2013, p. 360), é precisamente nesse ponto que é possível perceber uma mudança de abordagem radical no pensamento tardio de Marx: "O que caracteriza os últimos 15 anos de sua obra é, contudo, que agora essa reflexão [por exemplo, sobre a estruturação política de uma sociedade futura não mais capitalista, M.S.] se desenvolve sob a forma de uma crítica à filosofia da história, que com a recusa do materialismo histórico também recusa o eurocentrismo deste".

Sugiro aqui que essa remissão à dialética e à história dos escritos juvenis de Marx é inadequada, pois incompatível com a concepção de dialética desenvolvida em $O$ Capital. Contudo, disso não se segue que Marx tenha caído em contradição. A razão para tal é que as considerações sobre a teoria da história em $O$ Capital caem fora do escopo daquilo que é sistematicamente desenvolvido na parte precedente da obra, i.e., o desenvolvimento sistemático das formas sociais mediante as quais o capital leva a cabo sua dominação sobre os seres humanos. Como Marx faz suas considerações históricas fora desse âmbito sistemático também no prefácio - elas podem e devem ser criticadas com base na dialética de $O$ Capital.

No que se segue, quero abordar rapidamente a reação de Marx à recepção de sua concepção de história para, na sequência, argumentar que Marx mesmo parece ter se dado conta das ambivalências de sua concepção de história, especialmente nos seus últimos anos de vida. A favor dessa tese está o fato de que Marx parece ser linguisticamente mais cauteloso na formulação de suas teses acerca da teoria da história.

Numa Carta à Redação de "Otetschestwennyje Sapiski” Marx observa: "Qual aplicação meu crítico pode fazer desse esboço histórico [no parágrafo anterior, Marx havia apresentado brevemente o desenvolvimento do capitalismo na Europa Ocidental tal como exposto no capítulo 24 d'O Capital - M.S.] sobre a Rússia? Simplesmente somente a seguinte: se a Rússia tende a tornar-se uma nação capitalista conforme o modelo da Europa Ocidental - e nos últimos anos empreendeu muitos esforços nessa direção -, assim ela não

\begin{tabular}{|l|l|l|l|l|}
\hline Q Rovista Qialectus & Ano 9 & n. 18 & Outubro 2020 & p. 66-85 \\
\hline
\end{tabular}


conseguirá realizar isso sem antes ter transformado uma boa parte de seus agricultores em proletários; e uma vez arrancada para o turbilhão da economia capitalista, terá que suportar firmemente as leis desse sistema, exatamente como os outros povos profanos. Isso é tudo. Mas isso é muito pouco para o meu crítico. Ele precisa transformar integralmente o meu esboço histórico do surgimento do capitalismo na Europa Ocidental numa teoria históricofilosófica do desenvolvimento universal, que é prescrito à maneira de destino a todos os povos, sejam quais forem as circunstâncias históricas nas quais se encontrem, para finalmente chegar àquela formação econômica, que, com o maior impulso das forças produtivas do trabalho universal, assegura o desenvolvimento mais universal do ser humano" (MEW 19, p. 111).

A posição exposta nesta carta de 1877 é, em parte, antecipada no prefácio à edição francesa d'O Capital, ${ }^{27}$ onde Marx já observara: "O país industrialmente mais desenvolvido mostra agora àqueles países, que o seguem na escada industrial, a imagem de seu próprio futuro" (MEGA ${ }^{2}$ II.7, p. 12). ${ }^{28}$ Essa formulação é muito mais restrita do que aquela que encontramos no prefácio à primeira edição, que diz: “o país industrialmente mais desenvolvido mostra ao menos desenvolvido somente a imagem de seu próprio futuro" (MEW 23, p. 361). Esse afastamento de uma "teoria histórico-filosófica do desenvolvimento universal" permite que se atribua a Marx uma concepção uniforme de história? ${ }^{29}$

Na correspondência com a comunista russa Vera Sassulitsch, datada a março de 1881, Marx afirma categoricamente: "libertá-la de qualquer dúvida sobre a incompreensão da perspectiva da assim chamada minha teoria [da acumulação primitiva]", que "a 'inevitabilidade histórica' deste movimento está, portanto, restrita expressamente aos países da Europa Ocidental" (MEW 29, p. 242). Dessa forma, Marx parece estar convencido de que o desenvolvimento histórico pode assumir características diversas dentro de cada contexto social e cultural. Se isso procede, então também o modelo de fundamentação da inevitável transição histórica para o comunismo, que Marx desenvolvera nos anos 40, é posta em questão. Essa transição, pois, requer uma nova fundamentação Ora, como fica, agora, a transição ao comunismo, se ela não pode ser dialeticamente impulsionada ${ }^{30}$

\footnotetext{
27 Na sua correspondência com Vera Sassulitsch Marx faz menção precisamente a essa versão francesa de $O$ Capital. Compare-se os esboços dessa correspondência MEW 19, p. 384 ss.

28 Quanto a isso, ver Lindner, 2013, p. 361.

29 Nessas considerações, oriento-me pelas lúcidas teses de Lindner (2013). Ver especialmente p. 361 ss..

30 Para fins de clareza: a compreensão do capitalismo e de sua lógica, mesmo que ela seja o míssil mais temível lançado contra a burguesia, pois leva à formação de uma consciência revolucionária para Marx, não conduz por si só a queda do capitalismo.
}

\begin{tabular}{|l|l|l|l|l|}
\hline Revista Dialectus & Ano 9 & n. 18 & Outubro 2020 & p. 66-85 \\
\hline
\end{tabular}


Numa Carta a Carlo Cafiero, de 29.07.1879, Marx observa: “o desenvolvimento da produção capitalista produz as condições materiais necessárias para a emancipação do proletariado" (MEW 34, p. 384), mas em hipótese alguma Marx fala de um colapso automático desse modo de produção. ${ }^{31}$ Como pode, pois, a emancipação tornar-se efetiva? Como é possível fazer a transição ao comunismo? Com essa interrogação fundamental chegase a famosa tese de Marx formulada no Urtext von Zur Kritik der politischen Ökonomie: "Sua existência [do trabalhador assalariado livre, M.S.] é o resultado de um processo histórico doloroso da estruturação econômica da sociedade. Nesse ponto se mostra, de maneira determinada, como a forma de apresentação dialética somente é correta, se ela conhece os seus limites" (MEGA² II.2, p. 91).

A forma dialética de apresentação precisa, pois, conhecer os seus limites, e esses limites são demarcados pelo desenvolvimento de seu próprio objeto. Se por um lado a existência do trabalhador assalariado livre é pressuposição fundamental para o surgimento da sociedade produtora de mercadorias, apresentada dialeticamente em $O$ Capital, por outro, ele não pode ser deduzido da rede categorial apresentada dialeticamente. Ele é pressuposto. Da mesma forma, a transição para uma sociedade comunista não pode ser deduzida dialeticamente da apresentação das categorias da Crítica da Economia Política. Se o caráter crítico do projeto marxiano fica evidente ao demonstrar a historicidade das categorias com as quais a Economia Política Clássica opera, portanto a própria historicidade do modo de produção capitalista, assim também deve ficar claro que da compreensão positiva do negativo subsistente não se segue nenhum resultado positivo per se. A transformação em ato histórico de uma alternativa ao modo de produção capitalista ainda resta ser efetivada pelos sujeitos historicamente engajados, que compreenderam que o capitalismo está sistematicamente em oposição aos seus interesses vitais. Está-se, pois, diante de uma transição que não pode ser impulsionada dialeticamente, não obstante a apresentação dialética ilumine as razões pelas quais o modo de produção capitalista está em oposição aos interesses vitais dos trabalhadores. Se, pois, o capitalismo produz historicamente as condições para a emancipação do proletariado, enquanto sistema ele precisa ser superado historicamente e, com efeito, por caminhos "não cômodos", como Marx postula na Carta a Kugelmann, datada a 17 de março de 1868 (MEW 32, p. 541)..$^{32}$

\section{Considerações Finais}

31 Na literatura especializada, há uma ampla discussão sobre a assim chamada teoria do colapso.

32 Quanto a isso, ver Iber, 2005, p. 287 ss..

\begin{tabular}{|l|l|l|l|l|}
\hline Ronita Dialectus & Ano 9 & n. 18 & Outubro 2020 & p. 66-85 \\
\hline
\end{tabular}


O trabalho buscou evidenciar que a relação de Marx com Hegel, bem como com a Economia Política, teorias que apresentam, para Marx, as interpretações mais sofisticadas da Modernidade, não foi linear. Alfred Schmidt afirma que nos anos 50 Marx realizou uma segunda grande leitura da Lógica de Hegel, frente à primeira, da década 1840. Essa segunda leitura seria marcada por uma ênfase nos aspectos produtivos da Ciência da Lógica: "Em verdade, a estrutura metódica de sua obra [Marx, M.S.] repousa sobre uma segunda apropriação, que se inicia nos anos finais da década de 1850, da Grande Lógica de Hegel [...]” (1967, p. 32). Da mesma forma, Marx afirma: “O extraordinário material para a história da economia política, que está acumulado no Museu Britânico, o ponto de vista favorável que Londres garante para a observação da sociedade civil-burguesa, [...], determinaram-me a começar novamente desde o início e trabalhar criticamente o novo material” (MEW 13, p. 1011). Portanto, também em sua Crítica da Economia Política Marx perpassou um caminho não linear, que o fez recomeçar suas leituras desde o início, por ocasião de sua chegada em Londres. A espinha dorsal desta segunda leitura da Economia Política é seguramente o problema do valor. Como Marx escreve na Das Elend der Philosophie: "A teoria do valor de Ricardo é a exposição científica da vida econômica presente” (MEW 4, p. 81). Ou seja, o horizonte teórico ou o paradigma de análise do problema do valor é, pelo menos até $1847^{33}$, a teoria de Ricardo, que, aos olhos ainda do Marx tardio, é o ápice teórico da Escola Clássica. Não obstante essa avaliação positiva da contribuição de Ricardo ao desenvolvimento da Economia Política Clássica, não há como negar que do ponto de vista do Marx de O Capital, Ricardo fracassou no tratamento do problema do valor. Cumpre advertir, no entanto, que do fato de Marx fazer uma segunda leitura de Hegel e da Economia Política não se segue um abandono da primeira crítica a Hegel e à Economia Política. Ao contrário, essa segunda leitura decorre do conhecimento de Marx de que a crítica seja a Hegel seja à Economia Política só pode ser levada a cabo em toda a sua radicalidade se se romper com o paradigma conceitual dessas duas teorias. Mas, para tanto, é necessário medir forças com a teoria criticada. Também a relação entre dialética e história não saiu incólume dessa "segunda leitura".

Buscou-se, desse modo, apresentar a dialética na Crítica da Economia Política como uma dialética negativa (Arndt 1994, p. 230; 310), a qual é uma lógica do finito. "A essa dialética negativa interessa, na apreensão e exposição daquilo que é, mostrar, 'na

33 Assim como, segundo Arndt, a teoria da história de Marx até 1847 é uma teoria teleológica da história ancorada numa certa interpretação de Hegel.

\begin{tabular}{|c|c|c|c|c|}
\hline Rovita Didectus & Ano 9 & n. 18 & Outubro 2020 & p. 66-85 \\
\hline
\end{tabular}


compreensão positiva do subsistente‘ (Marx), a necessidade de sua negação. Essa necessidade não segue um mecanismo da suprassunção no absolutamente necessário (absolut-Notwendige) e não tem, nessa medida, nenhum resultado positivo determinado, que dela se sucederia obrigatoriamente e o qual poderia ser retido como predominando sobre o negativo" (1994, p. 230). Arndt distingue quatro formas de resolução da contradição em Hegel, contra as quais ele objeta, que já na construção da contradição no finito "[é posto] em funcionamento um mecanismo de suprassunção teleológico, o qual gradativamente destitui em seu ser as contradições existentes, no qual o resultado negativo, ao qual elas sucumbem, é reinterpretado teleologicamente na afirmação de uma esfera superior que procede da contradição" (1994, p. 216). Precisamente esse mecanismo de suprassunção teleológico é negado por uma dialética negativa. Não é irrelevante fazer menção a esse ponto, pois, como foi possível verificar, mesmo no Marx da Crítica da Economia Política ainda restaram alguns resquícios de um tal mecanismo de suprassunção, como a famosa tese da negação da negação no primeiro tomo d'O Capital. Tais teses são vestígios de um hegelianismo irrefletido, que assume um conceito de contradição dificilmente conciliável com uma dialética negativa, como se supõe ser a dialética n'O Capital. O contato de Marx com comunistas de países não europeus e o desenvolvimento de um novo conceito de contradição na Crítica da Economia Política parece terem levado Marx a abandonar o seu esquema de explicação da história universal desenvolvido em meados dos anos 40.

Marx parece ter percebido a tensão entre um método dialético que serve para "glorificar o existente" (MEW 23, p. 27), isto é, sua forma mistificada, e sua forma racional, "porque ela inclui na compreensão positiva do subsistente ela simultaneamente também a compreensão de sua negação, de seu necessário fenecer” (MEW 23, p. 28). Com isso, certamente ficou diante do impasse de se a nova sociedade fosse fundada numa dialética positiva, ela não seria também uma sociedade alienada, uma vez que ela não deve sua fundamentação à ação consciente dos trabalhadores livremente associados, mas a determinadas formas sociais que eles fazem valer de maneira irrefletida. Ora, precisamente a realização das formas sociais de maneira irrefletida parece estar no cerne da crítica de Marx à produção do capital e às formas de alienação por ela engendradas. Seria pouco convincente fundar uma sociedade livre e emancipada nesses termos.

\section{Referências:}

\begin{tabular}{|l|l|l|l|l|}
\hline Q Rovista Qialectus & Ano 9 & n. 18 & Outubro 2020 & p. 66-85 \\
\hline
\end{tabular}


ARNDT, Andreas. Dialektik und Reflexion. Hamburg: Felix Meiner, 1994.

Karl Marx Versuch über den Zusammenhang seiner Theorie. Berlin:

Akademie Verlag. 2011.

CASTORIADIS, Cornelius. Gesellschaft als imaginäre Institution. Frankfurt: Suhrkamp Verlag, 1990.

DÜSING, Klaus. Das Problem der Subjektivität in Hegels Logik. Bonn: Bouvier, 1976.

HEGEL, Georg. Vorlesungen über die Philosophie der Geschichte. Frankfurt: Suhrkamp, 1986. Citado como TW, Tomo, Página.

HEINRICH, Michael. Kritik der politischen Ökonomie. Stuttgart: Schmetterling Verlag, 2004.

HOFF, Jan. Befreiung heute: emanzipationstheoretisches Denken und historische Hintergründe. Hamburg: VSA Verlag, 2016.

IBER, Christian. Grundzüge der Marx`schen Kapitalismustheorie. Berlin: Parerga, 2005.

Platon Sophistes. Kommentar von Christian Iber. Studienbibliothek Suhrkamp. Frankfurt am Main: Suhrkamp, 2007.

. Subjektivität, Vernunft und ihre Kritik. Frankfurt am Main: Suhrkamp, 1999.

Hegels Konzeption des Begriffs. In: G.W.F. Hegel Wissenschaft der Logik. Koch, Anton Friedrich; Schick, Friedrike; (Org.). Berlin: Akademie Verlag, 2002.

LINDNER, Urs. Marx und die Philosophie. Stuttgart: Schmetterling Verlag, 2013.

MARX, K.; ENGELS, F.; Marx-Engels-Werke. 1962. Citado como MEW, Tomo, Página).

POSTONE, Moishe. Zeit, Arbeit und gesellschaftliche Herrschaft: eine neue Interpretation der kritischen Theorie von Marx. Freiburg: Ça Ira, 2003.

QUANTE, Michael. Karl Marx Ökonomisch-philosophische Manuskripte. Kommentar von Michael Quante. Studienbibliothek Suhrkamp. Frankfurt am Main: Suhrkamp, 2009.

SCHÄFER, Rainer. Dialektik und ihre besonderen Formen in Hegels Logik. Hamburg: Meiner, 2001.

SCHMIDT, Alfred. Zum Erkenntnisbegriff der Kritik der politischen Ökonomie. In: Walter Euchner, W.; Schmidt, A.; (ORG.). Kritik der politischen Ökonomie heute 100 Jahre „Kapital“. Referate und Diskussionen vom Frankfurter Colloquium 1967, Frankfurt am Main, p. $30-43,1967$.

VÁZQUEZ, Adolfo Sánchez. Filosofia y economia en el joven Marx. Ciudad de México: Grijalbo, 1982.

\begin{tabular}{|l|l|l|l|l|}
\hline Q Povista Dialectus & Ano 9 & n. 18 & Outubro 2020 & p. 66-85 \\
\hline
\end{tabular}

